Article

\title{
Exploratory Factors Influencing Building Development Costs in New Zealand
}

\author{
Linlin Zhao *, Jasper Mbachu and Niluka Domingo \\ School of Engineering and Advanced Technology, Massey University, 0632 Auckland, New Zealand; \\ J.I.Mbachu@massey.ac.nz (J.M.); N.D.Domingo@massey.ac.nz (N.D.) \\ * Correspondence: L.L.Zhao@massey.ac.nz
}

Received: 28 April 2017; Accepted: 15 June 2017; Published: 29 June 2017

\begin{abstract}
Identification of costs drivers and their influence level on building development costs play a key role in the development of construction models and improve the efficiency and effectiveness of any project. Forty-five indicators influencing building development costs in New Zealand are explored by literature review and pilot interviews. These indicators are grouped into seven categories. The determination and ranking of the cost drivers are carried out by a questionnaire survey distributed to key professionals working in New Zealand's construction industry. Structural equation modeling (SEM) software was employed for analysis of the collected data. One of the key advantages of this powerful software is to provide the $p$-value according to the structure of the research model. Findings of this study indicate that the property market and construction industry factor, statutory and regulatory factor, and socio-economic factors are major factors affecting building development costs in New Zealand.
\end{abstract}

Keywords: influencing factors; building development costs; New Zealand; structural equation modeling

\section{Introduction}

The construction industry is the fifth large sector in New Zealand, employing 8 percent of the total labor force, accounting for 10 percent of total businesses, and contributing 4 percent to GDP according to New Zealand Statistics [1]. Moreover, it is by far the largest investor of Gross Fixed Capital Formation (GFCF), which is the foundation of economic growth, contributing 45 percent of all investment in New Zealand [2]. In addition, the construction industry plays a more important role in New Zealand's economy than any other industry-apart from gas, electricity, and the waste and water sector-through its workers' income spending and its spending on the supply chain. However, the construction industry is usually characterized by the domination of small firms and low labor productivity. The small firms are invariably lacking a breadth and depth of finance of a type that invests in capital to improve productivity. Lack of economic scale in the construction industry, especially in the residential construction group, significantly increases building development costs.

Many studies have been conducted to explore the factors influencing building development costs from various perspectives. However, the influencing factors for these specific costs are varied for different countries; therefore, an appreciation of a country's examination of the influencing factors for building development costs is required. Building development costs have increased dramatically during the last decade [3]. In the New Zealand context, building development costs increased more than the annual average earnings in Auckland for the period 2009-2014 [4]. Building costs rose by 9.48 percent in the country's eight major cities in 2013 , up from the minimal year on year increase of 2.61 percent in 2012 [5].

The dramatic increases in building development costs are usually explained by the increase in the prices of building materials and labor [6]. However, the building material supply sector holds 
a different opinion. Although the costs of building materials have increased by 19 percent from 2002 to 2011, one-third of the increase is due to the changing nature of the building materials, and other building materials have experienced a rather modest increase [7]. As the above has given rise to different opinions, the main drivers behind the marked increase in building development costs remain unclear.

Exploring the relationship between building development costs and the significant influencing factors in the construction sector is vital to reliable cost estimation and cost management practices; fluctuations in building development costs could impact the decisions of investors, developers, clients, and financial institutions [8]. A more reliable and validated relationship between building development costs and influencing factors can assist the investors, developers, and contractors in making appropriate decisions and ensuring well-planned cost management.

Since the 1970s, most of the work in building project management has focused on project cost problems, assuming that the development of better cost estimating techniques would lead to better cost management and thus the successful completion of projects. However, there are many factors outside the control of management that can determine the costs of a project.

In the existing literature, these factors are referred to as critical influencing factors for building development costs and only a few studies have been conducted to assess, clarify, or analyze these factors. Most of the early studies in the area focused on the factors causing costs overruns in a project rather than factors influencing building development costs. Although some of the research and studies identify the factors influencing building development costs, they only centered on the project component costs, project-related factors, and stakeholders' influences factors.

Furthermore, the influencing factors for building development costs vary in various research and studies in the literature. Although the existing literature generated several lists of influencing factors for building development costs, they seem to tabulate individual factors rather than categorizing them according to some criteria, in order to facilitate the relationship between them and building development costs. In addition, in fact, many of the influencing factors do not have direct effects on building development costs.

Generally, a combination of some factors can affect the building development costs. The purpose of this study is to identify the factors influencing building development costs, classify the influencing factors into different categories, and reveal the effects of the influencing factors on building development costs in New Zealand. Thus, instead of assessing individual factors, there is a need to identify the category a factor belongs to at first, and then decide the combined effects of these influencing factors on building development costs.

The clients that decide to invest in the construction sector consider the building development costs as the most important factor [9]. A lack of extensive studies on the leading indicators that significantly influence building development cost is one issue that impacts clients' investment [8]. A study of the factors significantly influencing building development costs in New Zealand would not only contribute to narrowing the gap in existing knowledge but also provide an evidence base to support clients' investment decisions.

The study also contributes to methodological constructs by way of the detail description of structural equation modeling (SEM) and puts forward the framework for understanding the comprehensive and complex relationship between the latent factors and the building development costs.

\section{A Brief Literature Review}

Various factors significantly influence building development costs. Many studies have identified those factors that are significant in different countries. They all state that these factors are related to project characters, stakeholders' influences, the market and industry, statutory and regulatory regimes, socio-economic conditions, and the national and global environments within which they are operating. These, in turn, influence building development costs. 
Bubshait and Al-Juwairah [10] addressed the theory that component costs factors and stakeholders' influences are the key determinants for building development costs in Saudi Arabia by measuring 42 factors known to affect building development costs. Chan and Park [11] conducted a random sample survey in Singapore to evaluate the factors that significantly influence building development costs, and then generated a result showing that project characters and stakeholders' influences are the major contributors to those costs.

Elhag et al. [12] stated that market and industry factors impose a strong influence on building development costs in the UK after the analysis of their questionnaire results. Bari et al. [13] identified the factors, such as the statutory and regulation factors and socio-economic conditions which significantly influence the building development costs, by conducting a questionnaire survey. The previous study also revealed that the national and global dynamics could directly and indirectly influence the building development costs as the demands for construction products are materially decided by exogenous determinants [14].

Many studies have examined the factors influencing building development costs [15]; however, the influence levels of the identified factors vary due to differences in the regulatory regimes of the construction industries. Furthermore, these studies only focused on preliminary influential factors such as building cost components, project character, stakeholders' influence, and new technology innovations. They did not examine wider factors, which also have effects on building development costs. To mitigate the gap in the existing knowledge, this research aimed to examine the influences of a broad range of factors which have significant impacts on building development costs. Although many studies have examined the relationships between building development costs and influencing factors, only a few of them considered the effects of the macro-economy and policies that have underpinning effects on the aggregate economy [16].

It is necessary to explore the influencing factors for building development costs in New Zealand-it seems, according to literature reviewed-that so far no such investigation has been conducted in this area. This study evaluates and ranks the cost drivers involved in the various stages of the development of building projects by employing a questionnaire survey to obtain the opinions and perspectives of the randomly selected samples of key professionals in New Zealand.

\section{Selection of Key Factors and Rationalization}

Effective and efficient building cost planning is essential to ensuring that any building project is successful [17]. Thus, accurate cost estimating is required from the earliest stages of the building project. However, inaccuracy in cost estimation is high in New Zealand. This is especially due to difficulty in identifying those indicators that can significantly influence building development costs. The heart of this study is to explore the factors that have significant effects on building development costs in New Zealand.

Previous studies have decided on numerous factors influencing building development costs, while there is a high degree of similarity in the influencing factors across many building projects. However, these influencing factors do not necessarily follow suit. Several studies have been conducted in New Zealand to identify the cost-influencing factors, such as investor tendency, financing costs, relatively high material costs, shortage of skilled labor, increased population, and strict building code and health and safety regulations.However, these studies only focused on several indicators that influence building development costs. This study identified 45 indicators that influence building development costs and sorts them into seven categories based on the literature survey and the interviews with the key professionals.

The seven categories are project component cost factor (PCC), project characteristics factor (PCF), project stakeholders' influence factor (PSI), property market and construction industry factor (PMCI), statutory and regulatory factor (SRF), national and global dynamics (NGD), and the socio-economic factor (SEF). The bulk of the 45 indicators grouped under these seven latent factors have been regarded 
as measured variables. Table 1 summarizes these seven latent factors and their respective measured variables as the hypothetical construct of the study.

\section{Research Model Development and Conceptual Framework}

Identifying the influencing factors for building costs and grouping them are good initial steps towards successful cost management in building construction projects. Moreover, in order to further enhance the understanding of industry practitioners and ensure successful cost management, the grouping of the influencing factors of building development costs should be clearly understood. The conceptual research model consists of seven latent constructs: project component costs factor, project characteristics factor, project stakeholders' influences factor, property market and construction industry factor, statutory and regulatory factor, national and global dynamics, and socio-economic factor. The seven constructs are individually and collectively regarded as enablers of building development costs and measured by the indicators, as a composite set of indicators is an aggregation for measuring multi-dimensional concepts which are difficult to capture by a single indicator [18]. The latent constructs and corresponding measuring indicators are presented in Table 1 . The latent constructs and hypothesized relationships are explained in the following.

The previous literature was used to identify a theoretical framework with seven constructs for devising an instrument to test the relationship between the influencing factors and the building development costs in New Zealand. The first construct centers on the project component costs including design cost, construction cost and procurement cost [19-21]. It is a very complex and demanding task to select the suitable procurement practice for building projects. An appropriate procurement practice can improve the efficiency of the contract delivery system and then reduce the building development costs by probably 5 percent [22].

The second construct focuses on the influences of project characteristics on building development costs: project location and project complexity [23]. As far as the project characteristics are concerned, a poor job of adequately defining a project's complexity may result in a poor design basis, and thus adversely affect building project costs [24]. Procedure methods and contract types may also be viewed as project characteristics [25-27]. The misunderstanding of the procedures and methods may result in many delays on the construction site and thus drive up building costs. Contract type is also perceived as a key attribute to building costs, as an inappropriate contract may lead to many conflicts and misinterpretations, and, consequently, costly litigation and arbitration. Moreover, according to a study conducted by [11], a special requirement for a project, like the degree of high technology, may also drive up building costs.

Building construction projects are usually unique in nature owning to the processes and interactions with numerous parties who may have different interests and involvement in the project. The process of design and construction of projects constitutes a complex system that involves collaboration, interactions and negotiations among stakeholders [28,29]. The third construct is based on project stakeholders' influences, which includes clients' stakes and satisfaction [29], consultants and contractors' experience and expertise [30]. The external personnel influences on projects, such as suppliers and building officials, may be not directly involved in the construction projects but may be capable of affecting the project delivery process [31]. Stakeholders are able to influence and control project decisions and actions related to their level of power and other associated attributes in the project. Furthermore, the experience and expertise of the stakeholders may also have significant effects on the building project costs [30].

The fourth construct proposed is focused on the influences of the property market and construction industry on building development costs. This latent construct consists of the material market, labor market, level of competition, and market structure and size. Any one of these indicators can have significant effects on the property market and the construction industry due to the fact that they are able to impose a strong influence on resource allocation in the property market and construction industry [32-34]. Their fragmented nature and the restricted access to material and labor both hamper 
the growth of the construction industry in New Zealand [35]. A low level of technological demand in the private building sector has led to the easy entry which exists in the construction industry, and now the intense competition between contractors imposes risks on the construction industry [36]. Furthermore, the boom and bust cycle, the relationship of supply and demand, investment tendency, and housing sell/rental prices are also considered as property market and construction industry factors [37]. Boom and bust cycles are prevalent features of the property market in developed and developing countries around the world. A property market downturn can particularly affect investment and spending in sectors related to the property market, such as the construction industry, for example, reducing demand for new property, decreasing the value of property or cancelling of building projects due to a shortage of funding.

The indicators, which include building code and compliance, health and safety regulations, political policies, financial regulations and construction contract acts, are considered to be statutory and regulation factors [38-41]. The statutory and regulation regime composed of these indicators imposes the restriction on the projects operated by them; these can significantly influence the building development costs of the project [33]. Existing research also explored the fact that the regulation regime, including a wide range of government, state and local regulations, building codes, land use laws, and regulations related to fees, places lots of pressure on the projects and generates substantial costs [42,43].

National and global dynamic factors include indicators such as global political dynamics, natural forces, global economic trends, and global business sentiments. The global influence sources that can affect New Zealand's building development costs are largely from overseas financial markets and global commodity prices [44-46]. These factors will also have significant effects on the building development costs [33]. The GFC lasted around 15 months, and, until now, the economy in New Zealand has been in a slow recovery with a moderate increase in GDP [47]. Unexpected events occurring nationally and internationally will pose lots of risks to the construction industry, and these, in turn, yield substantial costs.

The socio-economic factors include GDP, CGPI, CPI, PPI, PI, LCI, net migration and population growth, employment rate, house prices, building consents, energy prices, exchange rate, monetary policies, investor confidence, and fiscal policies. All of these can have significant effects on the whole socio-economic situation. Construction projects conducted within socio-economic environments will be influenced on many levels, and these generate high costs. A study stated that the socio-economic factors have significant effects on building development costs, as highlighted by questionnaire analysis [27]. Moreover, research also considers that socio-economic factors can significantly influence building development costs after correlation analysis [48].

Using this framework of factors and dimensions of building development costs, a hypothetical diagram of the structural model incorporating these seven latent factors with their corresponding measured indicators, is presented in Figure 1. The structural model reveals the relationship between the building development costs and associated influencing factors. The direction of the arrows and the path loadings represent hypothetical, direct and indirect influences in the structural model. The corresponding hypotheses are listed below:

Hypothesis 1 (H1). Project component cost factor (PCC) significantly contributes to the building development costs in New Zealand.

Hypothesis 2 (H2). Project characteristics factor (PCF) significantly influences the building development costs in New Zealand.

Hypothesis 3 (H3). Project stakeholders' influence factor (PSI) has significant effects on the building development costs in New Zealand. 
Hypothesis 4 (H4). Property market and construction industry factor (PMCI) has significant effects on the building development costs in New Zealand.

Hypothesis 5 (H5). Statutory and regulation factor (SRF) has significant effects on the building development costs in New Zealand.

Hypothesis 6 (H6). National and global dynamic factor (NGD) has significant effects on the building development costs in New Zealand.

Hypothesis 7 (H7). Socio-economic factor (SEF) has significant effects on the building development costs in New Zealand.

Table 1. Latent constructs and corresponding indicators of the research model.

\begin{tabular}{|c|c|c|}
\hline Factors & Indicators & Source Reference \\
\hline Project Component Costs Factor (PCC) & $\begin{array}{l}\text { Design Costs (PCC1) } \\
\text { Construction Costs (PCC2) } \\
\text { Procurement Costs (PCC3) }\end{array}$ & {$[20,21]$} \\
\hline Project Characteristics Factor (PCF) & $\begin{array}{l}\text { Project Location (PCF1) } \\
\text { Complexity (PCF2) } \\
\text { Procedures Methods (PCF3) } \\
\text { Contract Types (PCF4) } \\
\text { Tech Innovations (PCF5) } \\
\end{array}$ & {$[23,25,26]$} \\
\hline Project Stakeholders Influences Factor (PSI) & $\begin{array}{l}\text { Clients (PSI1) } \\
\text { Consultants (PSI2) } \\
\text { Contractors (PSI3) } \\
\text { Suppliers (PSI4) } \\
\text { Building Officials (PSI5) } \\
\end{array}$ & {$[22,27,49,50]$} \\
\hline $\begin{array}{l}\text { Property Market and Construction } \\
\text { Industry Factor (PMCI) }\end{array}$ & $\begin{array}{l}\text { Material Market (PMCI1) } \\
\text { Labor Market (PMCI2) } \\
\text { Level of Competition (PMCI3) } \\
\text { Market Structure and Size (PMCI4) } \\
\text { Boom and Bust Cycle (PMCI5) } \\
\text { Supply and Demand (PMCI6) } \\
\text { Investment Tendency (PMCI7) } \\
\text { House R/S Prices (PMCI8) }\end{array}$ & {$[33,34,51,52]$} \\
\hline Statutory Regulatory Factor (SRF) & $\begin{array}{l}\text { Building Code and Compliance (SRF1) } \\
\text { Health and Safety Regulations (SRF2) } \\
\text { Political Policies (SRF3) } \\
\text { Financial Regulations (SRF4) } \\
\text { Construction Contract Act (SRF5) } \\
\end{array}$ & {$[38-43,53,54]$} \\
\hline $\begin{array}{l}\text { National and Global } \\
\text { Dynamics (NGD) }\end{array}$ & $\begin{array}{l}\text { Global Political Dynamics (NGD1) } \\
\text { Natural Forces (NGD2) } \\
\text { Global Economic Trend (NGD3) } \\
\text { Global Business Sentiments (NGD4) }\end{array}$ & {$[44-46,51,55,56]$} \\
\hline Socio Economic Factor (SEF) & $\begin{array}{l}\text { Gross Domestic Production (SEF1) } \\
\text { Capital Goods Prices (SEF2) } \\
\text { Customer Price Index (SEF3) } \\
\text { Producer Price (SEF4) } \\
\text { Construction Productivity (SEF5) } \\
\text { Labor Cost (SEF6) } \\
\text { Net Migration (SEF7) } \\
\text { Employment Rate (SEF8) } \\
\text { House Prices (SEF9) } \\
\text { Building Consents (SEF10) } \\
\text { Energy Prices (SEF11) } \\
\text { Exchange Rate (SEF12) } \\
\text { Monetary Policy (SEF13) } \\
\text { Investor Confidence (SEF14) } \\
\text { Fiscal Polices (SEF15) }\end{array}$ & {$[54,57-62]$} \\
\hline
\end{tabular}




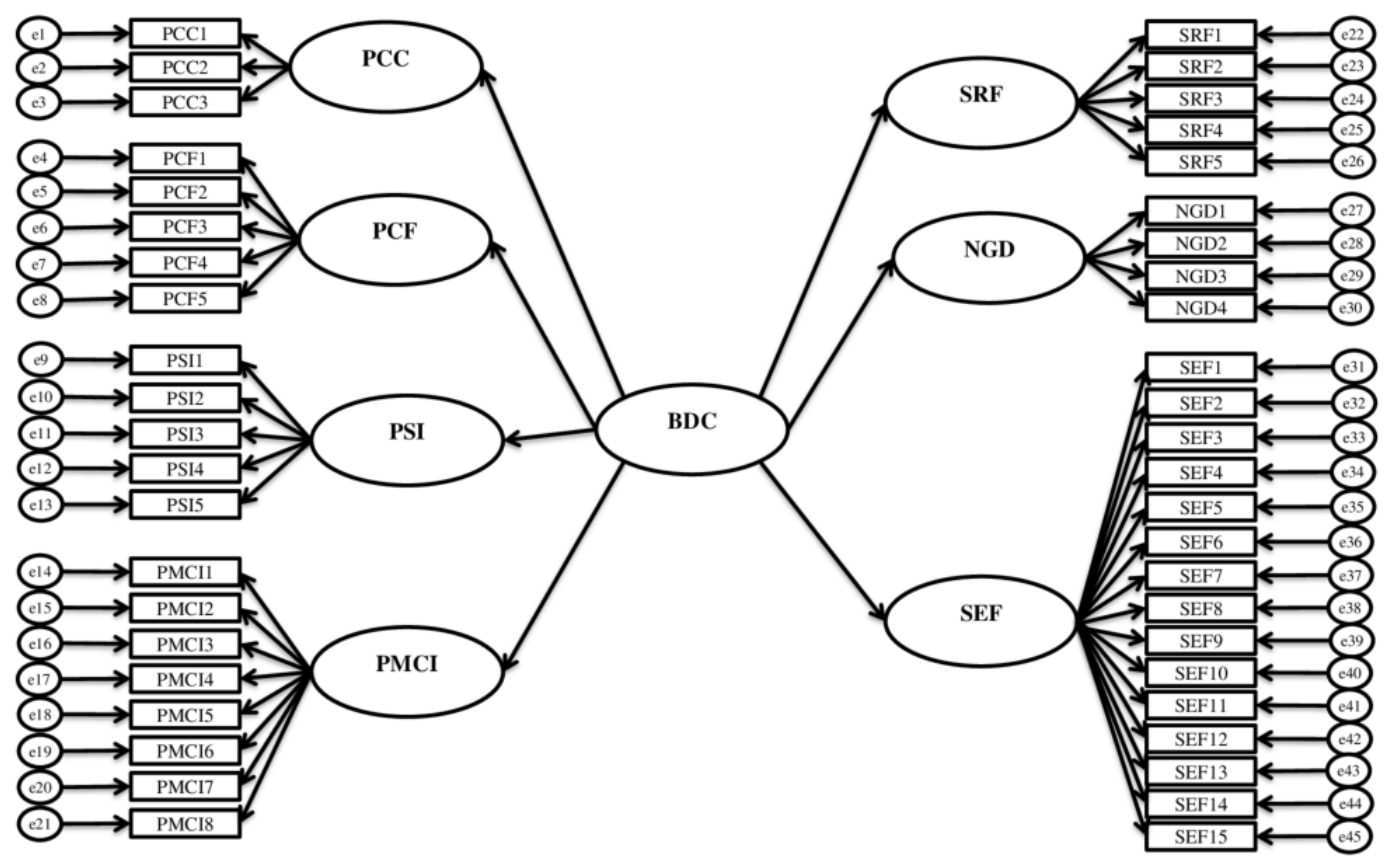

Figure 1. Structural research model.

\section{Methodology of Study}

Study into the cost-influencing factors for building development costs in New Zealand is a qualitative and quantitative endeavor. The selected methodologies depend on their applicability for collecting and processing the available data and generating the results that limit the threats to external and internal validity. The research methodology for the present study has adopted a questionnaire survey to test the conceptual model of building development costs in New Zealand based on theory framework. To identify indicators for seven latent constructs influencing building development costs, a literature review and interviews of key professionals of all parties involved in the construction industry were carried out. A questionnaire survey was framed as per the discussion with the experts through the pilot interview and then it was distributed to developers and clients, consultants, contractors and project managers of the New Zealand construction industry for the main survey. This study is carried out in three stages. First, the literature survey was conducted to find the factors influencing building development costs nationally and internationally. Then, the influencing factors were grouped into seven categories in accordance with a previous study by Akintoye [52].

Second, the pilot interview with the key professionals including developers, asset managers, consultants, and project managers was used to determine the indicators that impact the building development costs in New Zealand. The pilot interview plays a key role in modifying and improving the draft questionnaire survey before sending it out to the potential respondents. Forty-five indicators are identified and grouped as project component costs factors, project characteristics factors, stakeholders' influences factors, property market and construction industry factors, statutory and regulatory factors, national and global dynamics, and socio-economy factors. These categories comprehensively involve all the criteria that should be considered in the development of a building construction project in New Zealand. Moreover, the semi-structured interview with the experts from construction and related industries also adds validity to the results and conclusion of the study.

Finally, a questionnaire survey is used to decide and rank these cost drivers based on their influence level on building development costs. The survey questionnaires were distributed by sending a web-link to the potential respondents, all of whom are registered members of New Zealand associations and institutions, such as New Zealand Institute of Architects (NZIA), New Zealand Institute of Quantity Surveyors (NZIQS), New Zealand Institute of Building (NZIOB), Association of 
Consulting Engineers of New Zealand (ACENZ), Property Institute New Zealand (PINZ), and Property Council New Zealand (PCNZ).

The questionnaire survey consisted of two parts gathering evaluation of indicators influencing building development costs in New Zealand and information on respondents' profiles. For each indicator, the respondents were requested to rate using a five-point Likert-Scale of 1 to 5 ( 1 = Very Weak, 2 = Weak, 3 = Medium, $4=$ Strong, 5 = Very Strong).

Before undertaking a questionnaire survey, a pilot interview was conducted among a twelve member reference group explaining the research intention and questions in order to validate the contents for accurate translation of overall research model. Based on the feedback received, the questionnaire was refined and ethics clearance was obtained from the University Ethics Committee for undertaking the questionnaire survey. The data was collected from six associations/institutions of the construction industry in New Zealand. The target population of the questionnaire survey was developers, clients, consultants, contractors, and project managers.

Of the 1807 key professionals contacted, 334 responded; 325 of those were found to be usable, representing a response rate of 18 percent. This is a normal response rate for a questionnaire survey carried out in the construction industry, according to [12]. Of the individuals who responded to the questionnaire survey, 56 percent are from Auckland, 28 percent from Wellington, 12 percent from Christchurch, and 4 percent from other regions in New Zealand. In addition, 38 percent (123) are developers and clients, 36 percent (98) are consultants, while 32 percent (104) are contractors and project managers. Ninety percent of the respondents have had more than ten years of experience in the construction industry.

\section{Analytical Approach: The Application of SEM}

Structural equation modeling is a multivariate method, which examines the relationship among exogenous latent variables and endogenous latent variables [63]. Structural equation modeling (SEM) uses various types of theoretical models to describe the relationship among observed and latent variables, which provides the quantitative test for a researcher's hypothesis [64].

Structural equation modeling is widely used in psychology and sociology [65]. Although SEM has been commonly used in other disciplines, its application in construction management research is not widespread. As the construction management studies usually involved data difficult to quantify, SEM is capable of identifying the influence of latent factors on the measured phenomenon [66].

In Figure 1, the path arrows show the hypothetical relationship among the dependent variables and independent variables and measured indicators. The rectangular shapes indicate the observed variables that are the individual items on the questionnaire survey. There are several reasons for using SEM in this study. First, the latent variables are included in the model. Second, the study aims to examine the relationship between the latent variables. Third, structural equation modeling does not require data normally distributed as data from a perspective rating that is of unknown distribution. Finally, the SEM is capable of combining theoretical and empirical knowledge to advance understanding.

\section{Reliability of Constructs}

The reliability and validity of the constructs are essential for further analysis and arriving at reasonable research conclusions and results. The most widely used method for reliability testing is Cronbach's alpha. This study employed the SPSS 23 (IBM, New Yo) to do the Cronbach's alpha test for all of the eight constructs in the study shown in Table 2.

The alpha values for the eight constructs are acceptable as they range between 0.8 and 0.9 . Specifically, the reliability value of the component costs factor is 0.957 , and the property market and industry factor has a responsibility alpha value of 0.921 , while other constructs also report high reliability alpha values, as shown in Table 2 . Therefore, the reliability of the constructs is acceptable as the satisfied reliability value is higher than 0.7 as recommended by [67]. 
Table 2. Measurement scale of constructs.

\begin{tabular}{|c|c|c|c|}
\hline Latent Constructs & Indicators & Factor Loading & Cronbach's Alpha \\
\hline \multirow{3}{*}{$\begin{array}{l}\text { Project Component } \\
\text { Costs Factor } \\
\text { (PCC) }\end{array}$} & Design Costs (PCC1) & 0.582 & \multirow{3}{*}{0.957} \\
\hline & Construction Costs (PCC2) & 0.642 & \\
\hline & Procurement Costs (PCC 3 ) & 0.577 & \\
\hline \multirow{5}{*}{$\begin{array}{c}\text { Project } \\
\text { Characteristics } \\
\text { Factor (PCF) }\end{array}$} & Project Location (PCF1) & 0.748 & \multirow{5}{*}{0.871} \\
\hline & Complexity (PCF2) & 0.62 & \\
\hline & Procedures Methods (PCF3) & 0.71 & \\
\hline & Contract Types (PCF4) & 0.869 & \\
\hline & Tech Innovations (PCF5) & 0.786 & \\
\hline \multirow{5}{*}{$\begin{array}{c}\text { Project } \\
\text { Stakeholders } \\
\text { Influences } \\
\text { Factor } \\
\text { (PSI) }\end{array}$} & Clients (PSI1) & 0776 & \multirow{5}{*}{0.902} \\
\hline & Consultants (PSI2) & 0.813 & \\
\hline & Contractors (PSI3) & 0.899 & \\
\hline & Suppliers (PSI4) & 0.655 & \\
\hline & Building Officials (PSI5) & 0.492 & \\
\hline \multirow{8}{*}{$\begin{array}{l}\text { Property } \\
\text { Market } \\
\text { and } \\
\text { Construction } \\
\text { Industry } \\
\text { Factor } \\
\text { (PMCI) }\end{array}$} & Material Market (PMCI1) & 0.516 & \multirow{8}{*}{0.921} \\
\hline & Labor Market (PMCI2) & 0.556 & \\
\hline & Level of Competition (PMCI3) & 0.69 & \\
\hline & Market Structure and Size (PMCI4) & 0.469 & \\
\hline & Boom and Bust Cycle (PMCI5) & 0.498 & \\
\hline & Supply and Demand (PMCI6) & 0.691 & \\
\hline & Investment Tendency (PMCI7) & 0.684 & \\
\hline & House R/S Prices (PMCI8) & 0.641 & \\
\hline \multirow{5}{*}{$\begin{array}{l}\text { Statutory } \\
\text { Regulatory } \\
\text { Factor } \\
\text { (SRF) }\end{array}$} & Building Code and Compliance (SRF1) & 0.708 & \multirow{5}{*}{0.919} \\
\hline & Health and Safety Regulations (SRF2) & 0.816 & \\
\hline & Political Policies (SRF3) & 0.661 & \\
\hline & Financial Regulations (SRF4) & 0.695 & \\
\hline & Construction Contract Act (SRF5) & 0.529 & \\
\hline \multirow{4}{*}{$\begin{array}{l}\text { National } \\
\text { and Global } \\
\text { Dynamics } \\
\text { (NGD) }\end{array}$} & Global Political Dynamics (NGD1) & 0.567 & \multirow{4}{*}{0.895} \\
\hline & Natural Forces (NGD2) & 0.822 & \\
\hline & Global Economic Trend (NGD3) & 0.696 & \\
\hline & Global Business Sentiments (NGD4) & 0.451 & \\
\hline \multirow{15}{*}{$\begin{array}{l}\text { Socio } \\
\text { Economic } \\
\text { Factor } \\
\text { (SEF) }\end{array}$} & Gross Domestic Production (SEF1) & 0.472 & \multirow{15}{*}{0.88} \\
\hline & Capital Goods Prices (SEF2) & 0.67 & \\
\hline & Customer Price Index (SEF3) & 0.721 & \\
\hline & Producer Price (SEF4) & 0.637 & \\
\hline & Construction Productivity (SEF5) & 0.651 & \\
\hline & Labor Cost (SEF6) & 0.536 & \\
\hline & Net Migration (SEF7) & 0.617 & \\
\hline & Employment Rate (SEF8) & 0.452 & \\
\hline & House Prices (SEF9) & 0.656 & \\
\hline & Building Consents (SEF10) & 0.744 & \\
\hline & Energy Prices (SEF11) & 0.574 & \\
\hline & Exchange Rate (SEF12) & 0.732 & \\
\hline & Monetary Policies (SEF13) & 0.528 & \\
\hline & Investor Confidence (SEF14) & 0.807 & \\
\hline & Fiscal Policies (SEF15) & 0.684 & \\
\hline
\end{tabular}

\section{Analysis of the Structural Equation Model}

Confirmatory factor analysis was conducted to test the validity of the constructs in this study as the established relationship between the constructs and indicators, and the constructs are from the previous study. One important facet of confirmatory factor analysis is to test whether the constructs can be well explained by the related indicators [68]. The construct validity is acceptable when the factor loadings of the related indicators exceed 0.4 as suggested by Hair et al. [68]. The analysis results 
explore all the factor loadings of the indicators' range from 0.451 to 0.899 , which means all the values are satisfied; thereby the validity of the constructs is achieved.

After the reliability and validity test of the constructs, the Amos software was employed to draw the structural model including all the constructs and relative indicators. The goodness of fit indices generated from Amos output should reveal the good fit of the structural model in order to test the hypothesis. In this study, the structural model has achieved adequate fit identified by Chi-square, df, GFI, IFI, CFI, NFI, PGFI, TLI and RMSEA, shown in Table 3.

Table 3. Goodness of fit indices for the structural model.

\begin{tabular}{ccc}
\hline Goodness of Fit Indices & Recommended Level & $\begin{array}{c}\text { Structural } \\
\text { Model }\end{array}$ \\
\hline Chi-square/df & $<2$ Tabachnick and Fidell [69] & 1.009 \\
Goodness of Fit Index (GFI) & $>0.95$ Fan et al. [70] & 0.961 \\
Incremental Fit Index (IFI) & $>0.9$ Bollen [71] & 0.947 \\
Comparative Fit Index (CFI) & $>0.93$ Byrne [72] & 0.983 \\
Normed Fit Index (NFI) & $>0.9$ Bentler and Bonett [73] & 0.922 \\
Parsimony Goodness of fit (PGFI) & $>0.6$ Williams and Holahan [74] & 0.875 \\
Tucker-Lewis Index (TLI) & $>0.9$ Hoyle [75] & 0.979 \\
Root Mean Square Error of Approximation (RMSEA) & $<0.05$ MacCallum and Austin [76] & 0.001 \\
\hline
\end{tabular}

\section{Hypothesis Testing}

The regression result in Amos output explored the property market and the construction industry factor has significant positive effects on building development costs as the critical value is greater than the cut off value of 1.96, so the hypothesis is accepted. Moreover, the analysis result also revealed that statutory and regulatory factors can have a significant negative influence on building development costs; hence, the hypothesis is accepted.

In addition, the generated output also indicated that the socio-economic factors have significant positive effects on building development costs, thereby, the hypothesis is accepted. In sum, the analysis output explored that the property market and construction industry factors, statutory and regulatory factors and socio-economic factors can explain 48 percent of the total variance in building development costs. The hypothesis testing results are shown in Table 4.

Table 4. Hypothesis testing results.

\begin{tabular}{cccccc}
\hline Hypothesis & Std Estimate & S.E. & C.R. & $p$ & Hypothesis Accepted \\
\hline H1 & 0.145 & 0.076 & 1.892 & 0.058 & No \\
H2 & 0.119 & 0.071 & 1.66 & 0.097 & No \\
H3 & 0.137 & 0.076 & 1.806 & 0.071 & No \\
H4 & 0.226 & 0.09 & 2.51 & 0.023 & Yes \\
H5 & 0.121 & 0.065 & 1.867 & 0.062 & No \\
H6 & 0.214 & 0.096 & 2.23 & 0.029 & Yes \\
H7 & 0.175 & 0.085 & 2.07 & 0.035 & Yes \\
\hline
\end{tabular}

\section{Discussion of Results}

This research aims to explore the effects of influencing factors on building development costs in New Zealand, such as project component costs factors, project characteristics factors, project stakeholders' influences factors, property market and construction industry factors, statutory and regulatory factors, national and global dynamics factors, and socio-economic factors. The analysis results revealed that the property market and construction industry factors have significant positive effects on building development costs in New Zealand. This conclusion is supported by some previous studies $[32,36,37,77,78]$. 
Since the result identified the strong relationship between property market and construction industry factors and building development costs, it is suggested that the construction activities purchase all the resources from the construction industry and sell their products to the market. The building development costs are influenced by the resource supply (labor, material and plant) in the construction industry, and the relationship between supply and demand in the property market. Moreover, the other related indicators also have indirect effects on building development costs, such as competition level, market structure and size, and boom and bust cycle. Therefore, all of the indicators combine, as property market and construction industry factors can significantly influence building development costs in New Zealand.

Moreover, the result also identified that the statutory and regulatory factors have significant effects on building development costs in New Zealand; this corroborates well with several previous studies [79]. Based on the study of Roberti [80], the imposed regulatory effects on projects required by building codes can influence the building development costs of the project, including zone development fees, tip fees, and strict requirements raised for earthquake-prone zones. Further support from Page [81] found that the health and safety regulations also can influence building development costs as the stricter and complicated requirements for construction site and staff working on the site might have more money spent on the site management and staff safety training, thereby increasing the building development cost. In addition, some previous studies also identified that financial regulations can influence building development costs by directly influencing the cost of borrowing in the construction industry. Hence, the statutory and regulatory factors have significant effects on building development costs in New Zealand.

Finally, the result also revealed that socio-economic factors have significant effects on building development costs in New Zealand. Some previous studies have identified that socio-economic conditions can significantly influence building development costs as all economic activities-including construction activities and their associated costs-are influenced by socio-economic situations $[22,27,82,83]$. Furthermore, it had been stated previously that increases in population, employment and income have positive effects on building development costs as the increased population raises the need for housing, while the increase in employment requires more workplaces resulting in an increase in the demand for commercial buildings. In addition, the increased income boosts the demand for housing. Finally, monetary policy affects all economic activities and influences the supply of construction products in the construction industry and the demand for housing, which is also in line with previous studies [84].

This result suggests that building development costs in New Zealand are more influenced by the market and industry situation, regulatory regimes and the macro-economic environment rather than the primary and immediate direct factors, such as component costs factors, project characteristics factors and stakeholders' influence factors. However, the national and global dynamics also have minus effects on building development costs in New Zealand, which is not as the study previously assumed. This might be because the data involved in this study is mainly from professionals who worked in the construction industry and cannot provide information of national and global economic situations. The other reason might be that New Zealand is a relatively small and isolated economic zone that is not significantly influenced by global situations. However, one indicator-natural disasters-strongly influenced the construction industry in New Zealand; the Christchurch earthquake suddenly and dramatically increased the demand for housing and also was one of the key drivers for the increase in building development costs in New Zealand.

Project component costs factors did not show significant effects on building development cost movements. Although the design costs, procurement costs and construction costs comprise building development costs, they are more influenced by the market and industry, the regulatory regimes, and the macro-economy environment [85-87]. Project characteristics' factors also cannot significantly influence building development costs as the project location indicators are more influenced by the local market and industry factors, while procedure methods and contract types are more influenced by the statutory and regulatory factor. Project complexity and technology innovation applications 
are more influenced by the combination of market and industry factors, statutory and regulatory factors, and macro-economy factors. Thus, the project characteristics' factors are more influenced by the combination of market and industry factors, regulatory factors and macro-economy factors. In addition, stakeholders' influence should significantly impact the building development costs, but the analysis result did not identify that. This might be due to the people involved in the building projects being involved in many disciplines, with different interests, so that their effects on building development costs are varied and conflicting. Hence, their effects on building development costs are not significant as their influences might cancel out each other. It is not uncommon for conflicting interests to exist among project stakeholders, as identified by Olander and Landin [88].

\section{Conclusions}

There are a total 45 indicators that impact building development costs in New Zealand, as identified from the literature review and pilot interviews with key professionals working in the construction industry and related industries within New Zealand. Consequently, these indicators are grouped into seven categories following the classification from a previous study. Only three categories out of seven are considered by the respondents as factors that significantly influence building development costs in New Zealand.

The influencing factors for building development costs are usually listed as either very general factors or very specific factors for a particular project in a given context. However, lacking a comprehensive list makes it difficult not only for researchers to evaluate the movement of the building development costs but also for industry professionals to estimate the building development costs based on these factors. This study suggests a theory framework that classifies the influencing factors, and describes the impacts of these factors on building development costs in New Zealand.

The research model developed in this study presents the influencing factors in a more systematic way. Factor categories are formed, which help professionals understand the overlooked dimensions of building development costs.Today, cost performance is still one of the most important objectives for any building project. The successful cost performance of a project can be assured by identifying the factors that significantly influence building development costs. Thus, the industry professionals need a better understanding of critical influencing factors and how to identify and measure them. This paper emphasizes the importance of the understanding of those influencing factors.

This paper discussed the influencing factors for building development costs and their effects on building development costs in New Zealand. Evidence shows that poor cost estimation for building projects leads to both clients and contractors suffering significant financial losses. It is suggested that some underlying influencing factors pose more challenges to construction practitioners who have little knowledge and understanding of them.

In addition, they lack effective techniques to measure their effects on building development costs. The research model developed by SEM was evaluated and the analysis results indicate that influencing factors affecting building development costs can be successfully modeled and assessed. The model would be an important tool for construction professionals to increase their awareness, identify influencing factors, assess their impact, and take appropriate action.

Further research should be conducted to investigate whether the respondents from different disciplines possess different or discrepant views on the cost drivers and their influence levels. The cost drivers from this study can be used as parameters for any project cost estimating model that should be developed in New Zealand's construction industry.

Acknowledgments: This research is financially supported by the Chinese Scholarship Council and Building Research Association New Zealand (BRANZ). The appreciation should give the key professionals from the construction industry in New Zealand for providing their opinions, support and assistance.

Author Contributions: Linlin Zhao, Jasper Mbachu and Niluka Domingo designed the research methods; Linlin Zhao conducted the data survey and data analysis, Linlin Zhao wrote the paper.

Conflicts of Interest: The authors declare no conflict of interest. 


\section{Abbreviations}

The following abbreviations are used in this manuscript:

MDPI: Multidisciplinary Digital Publishing Institute

SEM: Structural Equation Modeling

NZ: New Zealand

NZIA: New Zealand Institute of Architects

NZIQS: New Zealand Institute of Quantity Surveyors

NZIOB: New Zealand Institute of Building

ACENZ: Association of Consulting Engineers of New Zealand

PINZ: Property Institute New Zealand

PCNZ: Property Council New Zealand

PCC: Project Component Costs

PCF: Project Characteristics Factor

PSI: Project Stakeholders Influences Factor

PMCI: Property Market and Construction Industry Factor

SRF: Statutory and Regulatory Factor

NGD: National and Global Dynamics

SEF: Social Economic Indicators

GFI: Goodness of Fit Indices

df: Degree of Freedom

IFI: Incremental Fit Index

CFI: Comparative Fit Index

NFI: Normed Fit Index

PGFI: Parsimony Goodness of Fit

TLI: Tucker-Lewis Index

RMSEA: Root Mean Square Error of Approximation

\section{References}

1. New Zealand Statistics (NZS). Global New Zealand International Trade, Investment, and Travel Profile; New Zealand Foreign Affairs and Trade: Wellington, New Zealand, 2013.

2. PWC. Valuing the Role of Construction in the New Zealand Economy, An Economic Analysis of Construction Sector; Construction Strategy Group (CSG): Auckland, New Zealand, 2011.

3. Boymal, J.; Silva, A.; Pomeroy, J. Quantity and quality estimates of changes in dwelling affordability in metropolitan Melbourne. Australas. J. Reg. Stud. 2013, 19, 64-84.

4. Helm, A. Auckland House Prices Continue Their Relentless Rise; The National Business Review: Auckland, New Zealand, 2014.

5. Delmendo, C. House Price Rises Accelerating in Australia; Global Property Guide (GPG): Bristol, UK, 2014.

6. Government Procurement Branch. Total Cost of Ownership; Ministry of Business, Innovation and Employment (MBIE): Wellington, New Zealand, 2013.

7. Cement and Concrete Association of New Zealand (CCANZ). Material Cost Report; CCANZ: Wellington, New Zealand, 2013.

8. Johnson, C.; Adelekan, I.; Bosher, L.; Jabeen, H.; Kataria, S.; Marome, A.W.; Zerjav, B.; Arefian, F. Private Sector Investment Decisions in Building and Construction: Increasing, Managing and Transferring Risks; The UNISDR 2013 Global Assessment Report; UNISDR: Geneva, Switzerland, 2013.

9. Grimsey, D.; Lewis, M. Are Public Private Partnerships Value for Money? Evaluating Alternative Approaches and Comparing Academic and Practitioner Views. Account. Forum 2005, 4, 345-378.

10. Bubshait, A.A.; Al-Juwairah, Y.A. Factors Contributing to Construction Costs in Saudi Arabia. Cost Eng. 2002, 44, 30-34.

11. Chan, S.L.; Park, M. Project Cost Estimation Using Principal Component Regression. Constr. Manag. Econ. 2005, 23, 295-304.

12. Elhag, T.M.S.; Boussabaine, A.H.; Ballal, T.M.A. Critical Determinants of construction tendering costs: Quantity Surveyor's standpoint. Int. J. Proj. Manag. 2005, 23, 535-545. 
13. Bari, N.A.A.; Yusuff, R.; Ismail, N.; Jaapar, A.; Ahmad, N. Factors influencing the Construction Cost of Industrialised Building System projects. Procdia Soc. Behav. Sci. 2012, 35, 689-696.

14. Ive, G.J.; Gruneberg, S.L. The Economics of the Modern Construction Sector; Palgrave Macmillan: London, UK, 2000.

15. Hwang, S. Dynamic Regression Models for Prediction of Construction Costs. J. Constr. Eng. Manag. 2009, 135, 360-367.

16. American Institute of Steel Construction (AISC). Understanding the Supply Chain; AISC: Chicago, IL, USA, 2014.

17. Son, H.; Kim, C. Hybrid principal component analysis and support vector machine model for predicting the cost performance of commercial building projects using pre-project planning variables. Autom. Constr. 2012, 27, 60-66.

18. Organisation for Economic Co-operation and Development (OECD). Handbook on Constructing Composite Indicators: Methodology and User Guide; OECD: Paris, France, 2008.

19. Knight, K.; Fayek, A.R. Use of Fuzzy Logic for Predicting Design Cost Overruns on Building Projects. J. Constr. Eng. Manag. 2002, 128, 503-512. [CrossRef]

20. Crompton, J.L.; Howard, D.R. Costs: The Rest of the Economic Impact Story. J. Sport Manag. 2013, $27,379-392$.

21. Griffis, F.H.; Choi, H. Design of public projects: Outsource or in-house? J. Manag. Eng. 2013, $29,2-9$. [CrossRef]

22. Ng, S.T.; Cheung, S.O.; Skitmore, R.M.; Lam, K.C.; Wong, L.Y. Prediction of tender price index directional changes. Constr. Manag. Econ. 2000, 18, 843-852. [CrossRef]

23. Harbuck, R.H. Competitive bidding for highway construction projects. AACE Int. 2004, EST.09, 1-3.

24. Cho, C.S.; Gibson, E.G. Building project scope definition using project definition rating index. J. Archit. Eng. 2001, 7, 115-125. [CrossRef]

25. Love, P.E.D.; Tse, R.Y.C.; Edwards, D.J. Time-cost relationships in Australian building construction projects. J. Constr. Eng. Manag. 2005, 131, 187-194. [CrossRef]

26. Qureshi, S.M.; Kang, C.W. Analyzing the organizational factors of project complexity using structural equation modeling. Int. J. Proj. Manag. 2015, 33, 165-176. [CrossRef]

27. Iyer, K.C.; Jha, K.N. Factors Affecting Cost Performance: Evidence from Indian Construction Projects. Int. J. Proj. Manag. 2004, 23, 283-295. [CrossRef]

28. Cheeks, J.R. Multistep disputes resolution in design and construction industry. J. Prof. Issues Eng. Educ. Pract. 2003, 129, 84-91.

29. Winch, G.M. Managing Construction Projects: An Information Processing Approach, 2nd ed.; Wiley-Blackwell: West Sussex, UK, 2010.

30. Memon, A.H.; Rahman, I.A.; Abdullah, M.R. Factors Affecting Construction Cost in Mara Large Construction Project: Perspective of Project Management Consultant. Int. J. Sustain. Constr. Eng. Technol. 2010, 1, 41-54.

31. Chinyio, E.; Olomolaiye, P. Construction Stakeholder Management; John Wiley and Sons Ltd.: Chichester, UK, 2010.

32. Watson, E. A Closer Look at Some of the Supply and Demand Factors Influencing Residential Property Markets; Reserve Bank of New Zealand: Wellington, New Zealand, 2013.

33. Grimes, A.; Hyland, S. Housing Market Dynamics and the GFC: The Complex Dynamics of a Credit Shock; Motu Economic and Public Policy Research: Wellington, New Zealand, 2013.

34. Shane, J.S.; Molenaar, K.R.; Anderson, S.; Schexnayder, C. Construction project cost escalation factors. J. Manag. Eng. 2009, 25, 221-229. [CrossRef]

35. Vaughan, G. A Range of Challenges Facing the Construction Industry Will Limit High Density Building and Intensification in Auckland; Reserve Bank of New Zealand: Wellington, New Zealand, 2016.

36. Ball, M. Markets and Institutions in Real Estate and Construction; Blackwell Publishing Ltd.: Oxford, UK, 2006.

37. Toh, T.C.; Ting, C.; Ali, K.N.; Aliagha, G.U.; Munir, O. Critical Cost Factors of Building Construction Projects in Malaysia. In Proceedings of the International Conference on Asia Pacific Business Innovation and Technology Management, Pattaya, Thailand, 13-15 January 2012.

38. Gundes, S. Exploring the dynamics of the Turkish construction industry using input-output analysis. Constr. Manag. Econ. 2011, 29, 59-68. [CrossRef]

39. Vincent, J.M.; Monkkonen, P. The impact of state regulations on the costs of public school construction. J. Educ. Financ. 2010, 35, 313-330. [CrossRef] 
40. Lyons, R.C. Housing supply in Ireland since 1990: The role of costs and regulation. J. Stat. Soc. Inq. Soc. Irel. 2014, 141.

41. Mumford, P.J. Enhancing Performance-Based Regulation: Lessons from New Zealand's Building Control System; Wellington, N.Z., Ed.; Institute of Policy Studies: Singapore, 2011.

42. Stephan, A.; Crawford, R.H. The relationship between house size and life cycle energy demand: Implications for energy efficiency regulations for buildings. Energy 2016, 116, 1158-1171. [CrossRef]

43. Titaya, S. Analyze on effect and building regulation in northern thailand's earthquake, May 2014: Chiangmai's residents risk perception and response to earthquake. Procedia Soc. Behav. Sci. 2016, 218, 85-94. [CrossRef]

44. New Zealand Institute of Economic Research (NZIER). The Home Affordability Challenge; NZIER: Wellington, New Zealand, 2014.

45. García, M.Á. Challenges of the construction sector in the global economy and the knowledge society. Int. J. Strateg. Prop. Manag. 2005, 9, 65-77.

46. Donaubauer, J.; Meyer, B.E.; Nunnenkamp, P. A new global index of infrastructure: Construction, rankings and applications. World Econ. 2016, 2, 236-259. [CrossRef]

47. Richardson, A. Can Global Economic Conditions Explain Low New Zealand Inflation; Reserve Bank of New Zealand: Wellington, New Zealand, 2015.

48. Akanni, P.O.; Oke, A.E.; Akpomiemie, O.A. Impact of environmental factors on building project performance in Delta State, Nigeria. Hous. Build. Natl. Res. Cent. 2014, 11, 91-97.

49. Wright, J.N. Time and budget: The twin imperatives of a project sponsor. Int. J. Proj. Manag. 1997, 15, 181-186. [CrossRef]

50. Naoum, S. An overview into the concept of partnering. Int. J. Proj. Manag. 2003, 21, 71-76. [CrossRef]

51. Chang, A.S.T. Reasons for cost and schedule increase for engineering design projects. J. Manag. Eng. 2002, 18, 29-36. [CrossRef]

52. Akintoye, A. Analysis of factors influencing project cost estimating practice. Constr. Manag. Econ. 2000, 18, 77-89. [CrossRef]

53. Mayer, C.J.; Somerville, C.T. Land use regulation and new construction. Reg. Sci. Urban Econ. 2000, 30, 639-662. [CrossRef]

54. Myers, D. Construction Economics: A New Approach; Routledge: Abingdon, UK, 2013.

55. Cesa-Bianchi, A. Housing cycles and macroeconomic fluctuations: A global perspective. J. Int. Money Financ. 2013, 37, 215-238. [CrossRef]

56. Alagidede, P. On the temporary and permanent components of global construction. Appl. Econ. Lett. 2016, 23, 284-289. [CrossRef]

57. Xu, M.; Grant-Muller, S.; Gao, Z.Y. Evolution and assessment of economic regulatory policies for expressway infrastructure in China. Transp. Policy 2015, 41, 42-49. [CrossRef]

58. Kosla, M.T. More than members: Market revitalization in the building trades. Crit. Soc. 2015, 41, 735-756.

59. Kaklauskas, A.; Kelpsiene, L.; Zavadskas, E.K.; Bardauskiene, D.; Kaklauskas, G.; Urbonas, M.; Sorakas, V. Crisis management in construction and real estate: Conceptual modeling at the Micro-, Meso- and Macro-levels. Land Use Policy 2011, 28, 280-293. [CrossRef]

60. Balló, Z. Dwellings and housing market in Hungary, 1990-2015. Procedia Eng. 2016, 161, 2079-2087. [CrossRef]

61. Wier, M. An environmental macro-economic model for the construction sector. Environ. Resour. Econ. 2000, 25, 323-341. [CrossRef]

62. Akintoye, A.; Bowen, P.; Hardcastle, C. Macro-economic leading indicators of construction contract prices. Constr. Manag. Econ. 1998, 16, 159-175. [CrossRef]

63. Hox, J.J.; Bechger, T.M. An introduction to structural equation modeling. Fam. Sci. Rev. 1998, 11, $354-373$.

64. Byrne, B.M. Structural Equation Modeling with AMOS Basic Concepts, Applications, and Programming, 3rd ed.; Routledge: Abingdon, UK, 2016.

65. Yang, J.B.; Ou, S.F. Using structural equation modeling to analyze relationships among key causes of delay in construction. Can. J. Civ. Eng. 2008, 35, 321-332.

66. Islam, M.D.M.; Faniran, O.O. Structural equation model of project planning effectiveness. Constr. Manag. Econ. 2005, 23, 215-223.

67. Pallant, J. SPSS Survival Manual: A Step by Step Guide to Data Analysis Using IBM SPSS; Allen and Unwin: Crows Nest, Australia, 2013. 
68. Hair, J.; Black, W.C.; Babin, B.J.; Anderson, R.E. Multivariate Data Analysis; Pearson Education International: Upper Saddle River, NJ, USA, 2010.

69. Tabachnick, B.G.; Fidell, L.S. Using Multivariate Statistics; Allyn and Bacon: Needham Heights, MA, USA, 2001.

70. Fan, X.; Thompson, B.; Wang, L. Effects of sample size, estimation methods, and model specification on structural equation modeling fit indexes. Struct. Equ. Model. 1999, 9, 56-83. [CrossRef]

71. Bollen, K.A. Structural Equations with Latent Variables; Wiley: New York, NY, USA, 1989.

72. Byrne, B.M. Structural Equation Modeling With Eqs and Eqs/Windows; Sage Publications: Thousand Oaks, CA, USA, 1994.

73. Bentler, P.M.; Bonett, D.G. Significant tests and goodness of fit in the analysis of covariance structures. Psychol. Bull. 1980, 88, 588-606. [CrossRef]

74. Williams, L.J.; Holahan, P.J. Parsimony-based fit indices for multiple-indicator models: Do they work? Struct. Equ. Model. 1994, 1, 161-189.

75. Hoyle, R.H. Structural Equation Modeling: Concepts, Issues, and Applications; Sage: Thousand Oaks, CA, USA, 1995.

76. MacCallum, R.C.; Austin, J.T. Applications of structural equation modeling in psychological research. Annu. Rev. Psychol. 2000, 51, 201-226. [CrossRef]

77. Chiang, Y.H.; Tang, B.S.; Leung, W.Y. Market structure of the construction industry in Hong Kong. Constr. Manag. Econ. 2001, 19, 675-687. [CrossRef]

78. Parke, W.; Warren, A. The Effects of Boom Bust on National Construction Industry Performance; Ministry for Business, Innovation and Employment (MBIE): Wellington, New Zealand, 2014.

79. Schill, M.H. Regulations and housing development: What we know. J. Policy Dev. Res. 2005, 8, 5-19.

80. Roberti, J.R. Trends in New Residential Construction in Auckland; Building Research Association New Zealand (BRANZ): Porirua, New Zealand, 2014.

81. Page, I.C. New House Price Modeling Study Report; Building Research Association New Zealand (BRANZ): Porirua, New Zealand, 2008.

82. Adams, Z.; Füss, R. Macroeconomic determinants of international housing markets. J. Hous. Econ. 2009, 19, 38-50. [CrossRef]

83. Wong, J.M.W.; Ng, S.T. Forecasting construction tender price index in Hong Kong using vector error correction model. Constr. Manag. Econ. 2010, 28, 1255-1268. [CrossRef]

84. Forni, M.; Gambetti, L. The dynamic effects of monetary policy: A structural factor model approach. J. Monet. Econ. 2009, 57, 203-216. [CrossRef]

85. Bygballe, L.E.; Hakansson, H.; Jahre, M. A critical discussion of models for conceptualizing the economic logic of construction. Constr. Manag. Econ. 2013, 31, 104-118. [CrossRef]

86. Dlamini, S. Relationship of construction sector to economic growth. In Proceedings of the International Congress on Construction Management, Montreal, QC, Canada, 26-29 June 2012.

87. Squicciarini, M.; Asikainen, A.L. A value chain statistical definition of construction and the performance of the sector. Constr. Manag. Econ. 2011, 29, 671-693. [CrossRef]

88. Olander, S.; Landin, A. Evaluation of stakeholder influence in the implementation of construction projects. Int. J. Proj. Manag. 2005, 23, 321-328. [CrossRef]

(C) 2017 by the authors. Licensee MDPI, Basel, Switzerland. This article is an open access article distributed under the terms and conditions of the Creative Commons Attribution (CC BY) license (http://creativecommons.org/licenses/by/4.0/). 